ISSN 0258-7122 (Print), 2408-8293 (Online)

Bangladesh J. Agril. Res. 41(4): 633-645, December 2016

\title{
EFFECT OF FERTILIZER MANAGEMENT ON PRODUCTIVITY OF POTATO-HYBRID MAIZE INTERCROPPING SYSTEM
}

\author{
A. A. BEGUM ${ }^{1}$, M. S. U. BHUIYA 2 , S. M. A. HOSSAIN ${ }^{2}$ \\ AMINA KHATUN ${ }^{3}$ AND S. K. DAS ${ }^{4}$
}

\begin{abstract}
The experiment was conducted at the research field of Agronomy Division, Bangladesh Agricultural Research Institute (BARI), Gazipur during 2011-12 to find out proper combination of fertilizer nutrients of potato hybrid maize intercropping system for higher productivity and economic return. Ten fertilizer dose viz., $\quad F_{1}=$ Control (without fertilizer), $\quad F_{2}={ }_{260} \mathrm{P}_{72} \mathrm{~K}_{148} \mathrm{~S}_{48} \mathrm{Zn}_{4} \mathrm{~B}_{2} \quad(100 \%$ recommended fertilizer, $R F$ for hybrid maize $H M$ ), $F_{3}=N_{180} P_{40} K_{180} S_{20} Z_{4} B_{1.2}$ ( $100 \%$ RF for potato), $\mathrm{F}_{4}=\mathrm{N}_{440} \mathrm{P}_{112} \mathrm{~K}_{328} \mathrm{~S}_{68} \mathrm{Zn}_{6} \mathrm{~B}_{2}(100 \% \mathrm{RF}$ for $\mathrm{HM}+100 \% \mathrm{RF}$ for potato), $\mathrm{F}_{5}=\mathrm{N}_{352} \mathrm{P}_{90} \mathrm{~K}_{262} \mathrm{~S}_{54} \mathrm{Zn}_{6} \mathrm{~B}_{2}(80 \% \mathrm{RF}$ for $\mathrm{HM}+80 \% \mathrm{RF}$ for potato), $\mathrm{F}_{6}=\mathrm{N}_{395} \mathrm{P}_{102} \mathrm{~K}_{283} \mathrm{~S}_{63} \mathrm{Zn}_{6} \mathrm{~B}_{2} \quad(100 \% \quad \mathrm{RF}$ for $\mathrm{HM}+75 \% \mathrm{RF}$ for potato $)$ $\mathrm{F}_{7}=\mathrm{N}_{350} \mathrm{P}_{92} \mathrm{~K}_{238} \mathrm{~S}_{58} \mathrm{Zn}_{6} \mathrm{~B}_{2}(100 \% \mathrm{RF}$ for $\mathrm{HM}+50 \% \mathrm{RF}$ for potato $), \mathrm{F}_{8}=$ $\mathrm{N}_{375} \mathrm{P}_{94} \mathrm{~K}_{291} \mathrm{~S}_{56} \mathrm{Zn}_{6} \mathrm{~B}_{2} \quad(100 \% \mathrm{RF}$ for potato $+75 \% \mathrm{RF}$ for $\mathrm{HM})$, $\mathrm{F}_{9}=\mathrm{N}_{310} \mathrm{P}_{76} \mathrm{~K}_{254} \mathrm{~S}_{44} \mathrm{Zn}_{6} \mathrm{~B}_{2}(100 \%$ RF for potato $+50 \% \mathrm{RF}$ for $\mathrm{HM})$ and $\mathrm{F}_{10}=\mathrm{N}_{320} \mathrm{P}_{73} \mathrm{~K}_{170} \mathrm{~S}_{50} \mathrm{Zn}_{6} \mathrm{~B}_{2} \mathrm{~kg} \mathrm{ha}^{-1}$ (BARI RF for potato hybrid maize intercropping) were tested on potato hybrid maize intercropping system. BARI Alu-8 (Cardinal) variety of potato and BARI Hybrid maize-7 variety of hybrid maize were used in this study. Maximum photosynthetically active radiation interception, leaf area index and total dry matter production of intercropped potato and maize were observed at the highest fertilizer level $\mathrm{N}_{440} \mathrm{P}_{112} \mathrm{~K}_{328} \mathrm{~S}_{68} \mathrm{Zn}_{6} \mathrm{~B}_{2} \mathrm{~kg} \mathrm{ha}^{-1}(100 \%$ RF for $\mathrm{HM}+100 \% \mathrm{RF}$ for potato). The highest tuber yield of potato $\left(30.20 \mathrm{t} \mathrm{ha}^{-1}\right)$ and grain yield of maize $\left(9.48 \mathrm{t} \mathrm{ha}^{-1}\right)$ were observed from fertilizer dose of $\mathrm{N}_{375} \mathrm{P}_{94} \mathrm{~K}_{291} \mathrm{~S}_{56} \mathrm{Zn}_{6} \mathrm{~B}_{2}(100 \% \mathrm{RF}$ for potato $+75 \% \mathrm{RF}$ for $\mathrm{HM})$. The highest potato equivalent yield $\left(40.47 \mathrm{t} \mathrm{ha}^{-1}\right)$, gross return $\left(\mathrm{Tk} .526110 \mathrm{ha}^{-1}\right)$, gross margin $(\mathrm{Tk}$. $381957 \mathrm{ha}^{-1}$ ) and benefit cost ratio (3.65) were also observed from the same fertilizer rate. The results revealed that fertilizer dose of $\mathrm{N}_{375} \mathrm{P}_{94} \mathrm{~K}_{291} \mathrm{~S}_{56} \mathrm{Zn}_{6} \mathrm{~B}_{2} \mathrm{~kg}$ $\mathrm{ha}^{-1}(100 \% \mathrm{RF}$ for potato $+75 \% \mathrm{RF}$ for $\mathrm{HM})$ might be economically profitable for potato hybrid maize intercropping system.
\end{abstract}

Keywords: Fertilizer management, potato, hybrid maize, intercropping.

\section{Introduction}

Potato (Solanum tuberosum L.) is one of the most important foods as well as vegetable crops in Bangladesh and is being cultivated throughout the country. It occupies topmost position after rice and wheat both in respect of production and

${ }^{1}$ Senior Scientific Officer, Agronomy Division, Bangladesh Agricultural Research Institute (BARI), Gazipur-1701, 2Professor, Bangladesh Agricultural University (BAU), Mymensingh- 2200, ${ }^{3}$ Senior Scientific Officer, RFS Division, Bangladesh Rice Research Institute (BRRI), Gazipur-1701, ${ }^{4}$ Regional Director, Bangladesh Betar, Takurgaon, Bangladesh. 
consumption (Akhtar et al., 1998). Its potential yield is estimated $25-35 \mathrm{t} \mathrm{ha}^{-1}$ in Bangladesh (Hossain et al., 2008). Potato is now becoming an important food for ensuring food security in Bangladesh. Conversely, maize (Zea mays L.) is the third most important food grain for human after rice and wheat. It is the primary staple food in many developing countries (Morris et al., 1999). Maize in Bangladesh is becoming an important crop in the rice-based cropping pattern. In recent years maize is gaining popularity among the farmers mainly due to high yield, more economic return and versatile uses.

Potato and maize may be grown as intercrop as they have different photosynthetic pathway, growth habit, growth duration and demand for growth resources (Chand et al., 2001). Intercropping system becomes productive and economical only when it is done properly by selecting compatible crops (Santalla et al., 2001), by shifting the period of peak demand for growth resources through changing the time of sowing of the component crops (Santalla et al., 1999). Fertilizer management is another important agronomic management practice for intercropping system productivity of potato hybrid maize intercropping system (Akhteruzzaman et al., 2008). But both the crops are exhaustive which removes substantial amount of nutrients from the soil. Supplementation or nutrients may improve growth and development of component crops, which may raise productivity of the system as a whole. Islam (2007) reported that $75 \%$ level of NPK for potato along with full recommended dose of fertilizers for maize was the most potential agro-economic level of NPK for potato maize intercropping. However, many studies on fertilizer management have been done in home and abroad on the aforesaid crops individually but very few studies have been reported on intercropping. Information relating complex behaviour of potato hybrid maize under proper dose of fertilizer application is not adequately available. So to understand the nature and extent of competition and complementarities of component crops, the present experiment was undertaken to find out the proper combination of fertilizer nutrients for potato hybrid maize intercropping system for higher productivity and economic return.

\section{Materials and Method}

The experiment was conducted at the Agronomy Research field of Bangladesh Agricultural Research Institute (BARI), Joydebpur, Gazipur during rabi season of 2011-12. The soil of the experimental field was Chhiata clay loam having $\mathrm{pH}$ 6.49 , organic matter $1.08 \%$, total $\mathrm{N} 0.034(\%)$, potassium $0.18 \mathrm{meq} / 100 \mathrm{~g}$ soil, phosphorus $13.5 \mathrm{ppm}$, sulphur $14.5 \mathrm{ppm}$, zinc $1.13 \mathrm{ppm}$ and boron $0.21 \mathrm{ppm}$. Maximum and minimum temperatures ranged from 24.20 to 34.28 and 12.30 to $24.35^{\circ} \mathrm{C}$, respectively during the study period. Average monthly rainfall for this period was $42.43 \mathrm{~mm}$ where maximum rainfall was recorded $141.00 \mathrm{~mm}$ and minimum $2.00 \mathrm{~mm}$. Ten fertilizer dose viz., $\mathrm{F}_{1}=$ Control (without fertilizer), 
$\mathrm{F}_{2}=\mathrm{N}_{260} \mathrm{P}_{72} \mathrm{~K}_{148} \mathrm{~S}_{48} \mathrm{Zn}_{4} \mathrm{~B}_{2}$ (100\% recommended fertilizer, RF for hybrid maize $\mathrm{HM}$ ), $\mathrm{F}_{3}=\mathrm{N}_{180} \mathrm{P}_{40} \mathrm{~K}_{180} \mathrm{~S}_{20} \mathrm{Zn}_{4} \mathrm{~B}_{1.2}\left(100 \%\right.$ RF for potato), $\mathrm{F}_{4}=\mathrm{N}_{440} \mathrm{P}_{112} \mathrm{~K}_{328} \mathrm{~S}_{68} \mathrm{Zn}_{6} \mathrm{~B}_{2}$ (100\% RF for $\mathrm{HM}+100 \%$ RF for potato), $\mathrm{F}_{5}=\mathrm{N}_{352} \mathrm{P}_{90} \mathrm{~K}_{262} \mathrm{~S}_{54} \mathrm{Zn}_{6} \mathrm{~B}_{2}$ (80\% RF for $\mathrm{HM}+80 \% \mathrm{RF}$ for potato), $\mathrm{F}_{6}=\mathrm{N}_{395} \mathrm{P}_{102} \mathrm{~K}_{283} \mathrm{~S}_{63} \mathrm{Zn}_{6} \mathrm{~B}_{2}$ (100\% RF for $\mathrm{HM}+75 \%$ $\mathrm{RF}$ for potato), $\mathrm{F}_{7}=\mathrm{N}_{350} \mathrm{P}_{92} \mathrm{~K}_{238} \mathrm{~S}_{58} \mathrm{Zn}_{6} \mathrm{~B}_{2}(100 \% \mathrm{RF}$ for $\mathrm{HM}+50 \% \mathrm{RF}$ for potato), $\mathrm{F}_{8}=\mathrm{N}_{375} \mathrm{P}_{94} \mathrm{~K}_{291} \mathrm{~S}_{56} \mathrm{Zn}_{6} \mathrm{~B}_{2}(100 \% \mathrm{RF}$ for potato $+75 \% \mathrm{RF}$ for $\mathrm{HM})$, $\mathrm{F}_{9}=\mathrm{N}_{310} \mathrm{P}_{76} \mathrm{~K}_{254} \mathrm{~S}_{44} \mathrm{Zn}_{6} \mathrm{~B}_{2}(100 \% \mathrm{RF}$ for potato $+50 \% \mathrm{RF}$ for $\mathrm{HM})$ and $\mathrm{F}_{10}=\mathrm{N}_{320} \mathrm{P}_{73} \mathrm{~K}_{170} \mathrm{~S}_{50} \mathrm{Zn}_{6} \mathrm{~B}_{2} \mathrm{~kg} \mathrm{ha}^{-1}$ (BARI RF for potato hybrid maize intercropping) were tested on potato hybrid maize intercropping system. The experiment was laid out in randomized complete block design with three replications. The unit plot size was $6.0 \mathrm{~m} \times 5.0 \mathrm{~m}$. BARI Alu-8 (Cardinal) variety of potato and BARI Hybrid maize-7 variety of maize were used in the experiment. Potato was planted on 22 November 2011 maintaining $75 \mathrm{~cm} \times 20$ $\mathrm{cm}$ spacing. Maize was sown on 22 December 2011 in between two potato rows with a spacing of $20 \mathrm{~cm}$. The source of $\mathrm{N}, \mathrm{P}, \mathrm{K}, \mathrm{S}, \mathrm{Zn}$ and $\mathrm{B}$ was urea, triple super phosphate (TSP), muriate of potash (MoP), gypsum, zinc sulphate and boric acid, respectively. One- third (1/3) urea was applied as basal, 1/3 at 30 days after planting (DAP) and 1/3 after potato harvest followed by irrigation. All other fertilizers were applied as basal except MoP. Half MoP was applied as basal and $1 / 2$ at 30 DAP of potato. Irrigation and other intercultural operations were done as and when required. Fungicide (Dithane M-45) was sprayed at every 10-day intervals beginning from 25 to 70 DAP for preventing potato disease. Photosynthetically active radiation (PAR) was measured by PAR Ceptometer (Model - LP-80, Accu PAR, Decagon, USA). Photosynthetically active radiation (PAR) was measured at 60, 68, 76, 84 and 92 DAP of potato at around 11:30 A.M. to 13:00 P.M. Plants were sampled at 15 day intervals from 30 to maturity for potato and 20 day intervals from 30 to 130 days after sowing for maize and green leaf area was measured by an automatic leaf area meter (Model: LI-300, USA). Plant materials were oven dried at $70^{\circ} \mathrm{C}$ to a constant weight and dry weight taken. Potato was harvested on 24 February 2012 (95 DAP) and hybrid maize on 6 May 2012 (135 DAS). Yield components of potato and maize were taken from randomly selected five plants from each plot at harvest. Yield of both crops were taken from whole plot. Potato equivalent yield was computed by converting yield of intercrops on the basis of prevailing market price of individual crop following the formula of Bandyopadhyay (1984) as given below:

Potato equivalent yield $=\mathrm{Yip}+(\mathrm{Yim} \times \mathrm{Pm}) / \mathrm{Pp}$

Where, Yip $=$ Yield of intercrop potato, Yim $=$ Yield of intercrop maize, $\mathrm{Pp}=$ Market price of potato and $\mathrm{Pm}=$ Market price of maize.

Collected data of both the crops were analyzed statistically and the means were adjudged using DMRT and $r$ value was done following the Microsoft Excel 2003. Economic analysis was also done considering local market price of harvested crops. 


\section{Results and Discussion}

\section{Per cent interception of photosynthetically active radiation}

The interception of light and its distribution within a plant canopy is an important determinant for the productivity of crop. The rate of dry matter production in crops is often proportional to intercepted radiation (Biscoe and Gallagher, 1977). In the present study, PAR interception was significantly influenced at all time intervals by intercropping system. PAR interception increased with increase of LAI due to higher fertilizer dose over the growing periods (Fig. 1). LAI increased with the progress of canopy coverage which intercepted more PAR energy for photosynthesis. Over the growing periods, the higher PAR interception was observed with higher LAI due to higher fertilizer and the lower was with lower LAI due to lower fertilizer. Higher fertilizer enhanced canopy coverage and intercepted higher PAR energy. At 60 DAP, PAR interception was the highest in all the treatments (Fig. 1). At the highest growth period (at 60 DAP), more than 95\% PAR was intercepted with $\mathrm{F}_{4}(100 \% \mathrm{RF}$ for $\mathrm{HM}+100 \% \mathrm{RF}$ for potato) fertilized treatment and it was statistically similar with all other treatments except control, $100 \%$ RF for HM and $100 \%$ RF for potato treatments. PAR interception was the lowest $(48 \%)$ with control treatment. Higher light/ PAR interceptions with higher leaf area were also reported by Maddonni and Otegui (2004). Flenet et al. (1996) reported that 95\% light interception is needed for better biological as well as economic yield. Higher fertilizer dose increased the LAI, which had interception of more PAR energy that was converted it to higher TDM. However, LAI, PAR interception, TDM increased with the increase of fertilizer dose and that was reflected at the $\mathrm{F}_{4}\left(100 \% \mathrm{RF}\right.$ for $\mathrm{HM}+100 \% \mathrm{RF}$ for potato), $\mathrm{F}_{5}(80 \%$ $\mathrm{RF}$ for $\mathrm{HM}+80 \% \mathrm{RF}$ for potato), $\mathrm{F}_{6}(100 \% \mathrm{RF}$ for $\mathrm{HM}+75 \% \mathrm{RF}$ for potato), $\mathrm{F}_{7}\left(100 \% \mathrm{RF}\right.$ for $\mathrm{HM}+50 \% \mathrm{RF}$ for potato) and $\mathrm{F}_{8}(100 \%$ RF for potato $+75 \%$ $\mathrm{RF}$ for HM) treatments which produced higher LAI, intercepted greater PAR energy, produced higher TDM and ultimately higher grain yield.

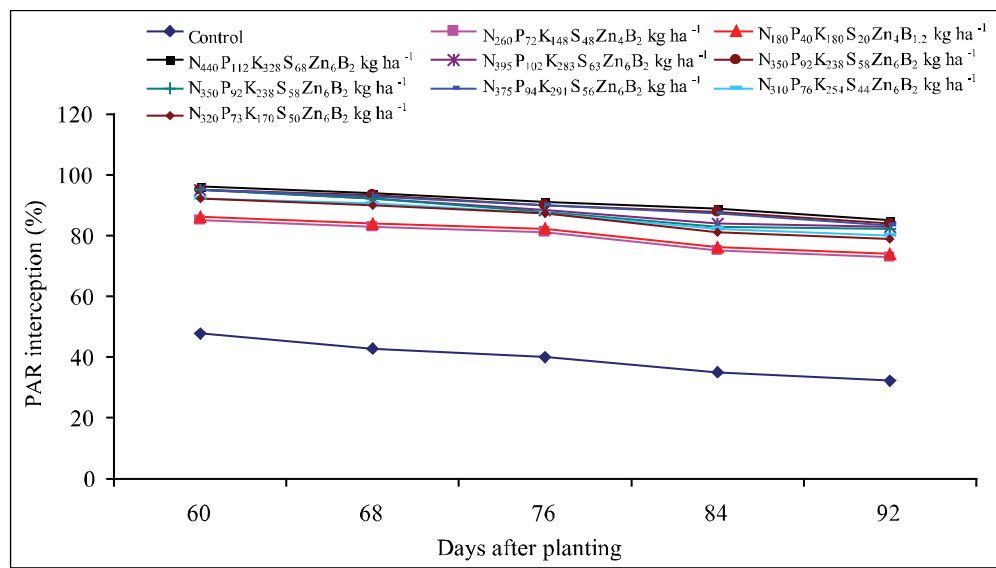

Fig. 1. Photosynthetically Active Radiation (\%) intercepted by potato and maize in potato hybrid maize intercropping system over days after planting. 
Functional relationship between PAR interception and potato equivalent yield indicated that potato equivalent yield was positively related to PAR intercepted by potato + maize in potato maize intercropping system (Fig. 2). The functional relationship suggested that $87 \%\left(\mathrm{R}^{2}=0.8723\right)$ of the variation in potato equivalent yield could be explained from the variation in PAR interception. On an average, potato equivalent yield could be increased at the rate of $0.8922 \mathrm{t} \mathrm{ha}^{-1}$ with an increase in $1 \%$ of PAR.

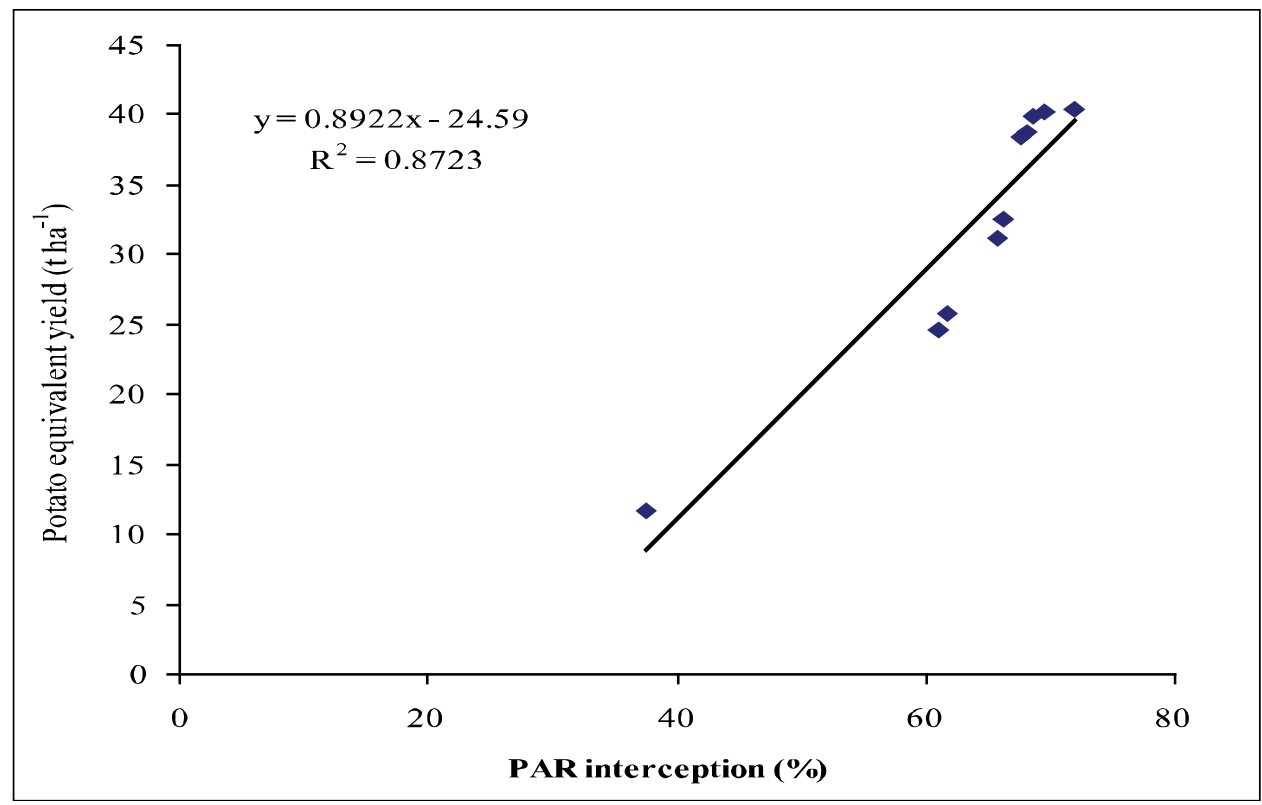

Fig. 2. Functional relationship between PAR interception and potato equivalent yield in potato maize intercropping pattern as affected by fertilizer level.

\section{Leaf area index of potato and hybrid maize}

Leaf area development in intercropped potato and maize are presented in Figs. 3 and 4. The LAI in potato and maize varied significantly in all the harvest intervals. The LAI increased sharply with the advancement of time up to 60 DAP in potato and 90 DAS in maize by applied different fertilizer doses and thereafter decreased. The rate of decreased LAI in the later part of growing season was higher in potato than that of maize. The decrease might be due to senescence of old leaves. LAI of potato and maize increased markedly with the increase of fertilizer levels. The highest LAI of intercropped potato (3.20) and maize (4.25) was observed at the highest level of fertilizer $\mathrm{N}_{440} \mathrm{P}_{112} \mathrm{~K}_{328} \mathrm{~S}_{68} \mathrm{Zn}_{6} \mathrm{~B}_{2} \mathrm{~kg} \mathrm{ha}^{-1}$ (100\% $\mathrm{RF}$ for $\mathrm{HM}+100 \% \mathrm{RF}$ for potato). The LAI of both potato and maize reduced under lower level of fertilizer and the lowest LAI was found in plants grown without fertilizer. The increase in LAI with the increase in fertilizer might be due to increase in availability of plant nutrients. These findings are in agreement with 
that of Islam (2007). He observed that the least LAI was found with the lowest level of NPK in intercropping involving potato + maize in all the growth stages and it was increased significantly with each successive increase of NPK level. The LAI of potato and maize was found positively correlated with tuber yield ( $\mathrm{r}$ $=0.93)$ and grain yield $(r=0.99)$, respectively.

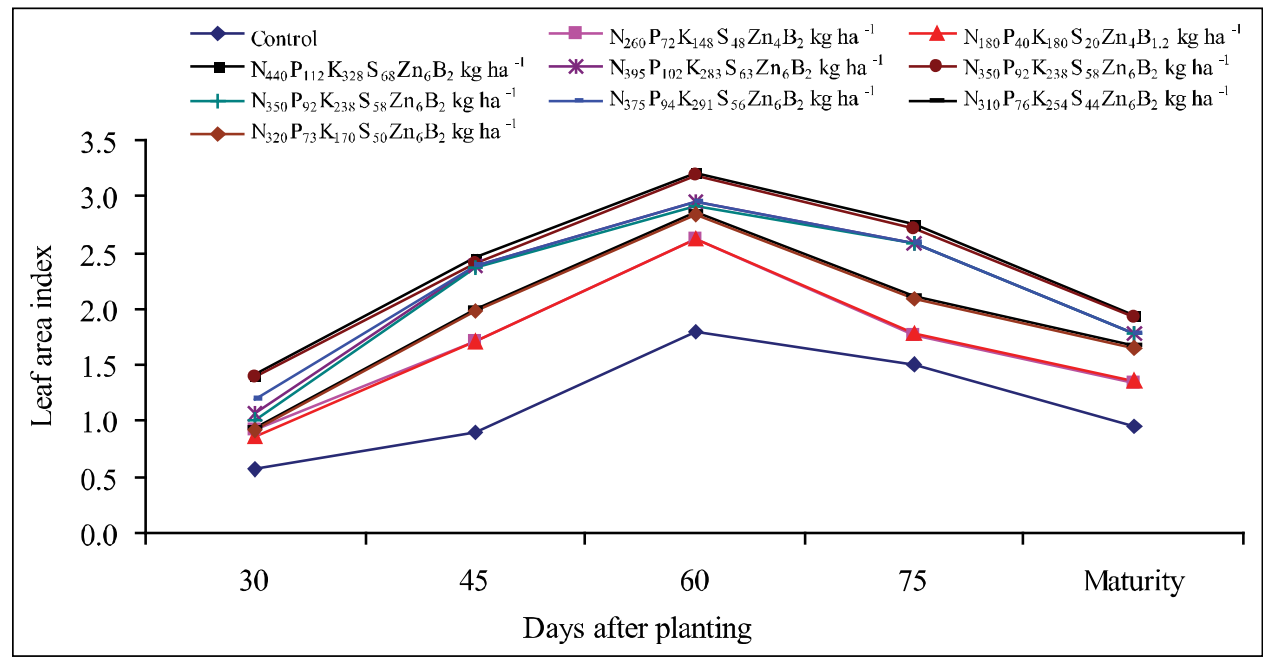

Fig. 3. Leaf area index of potato in potato hybrid maize intercropping system under different fertilizer level over days after planting.

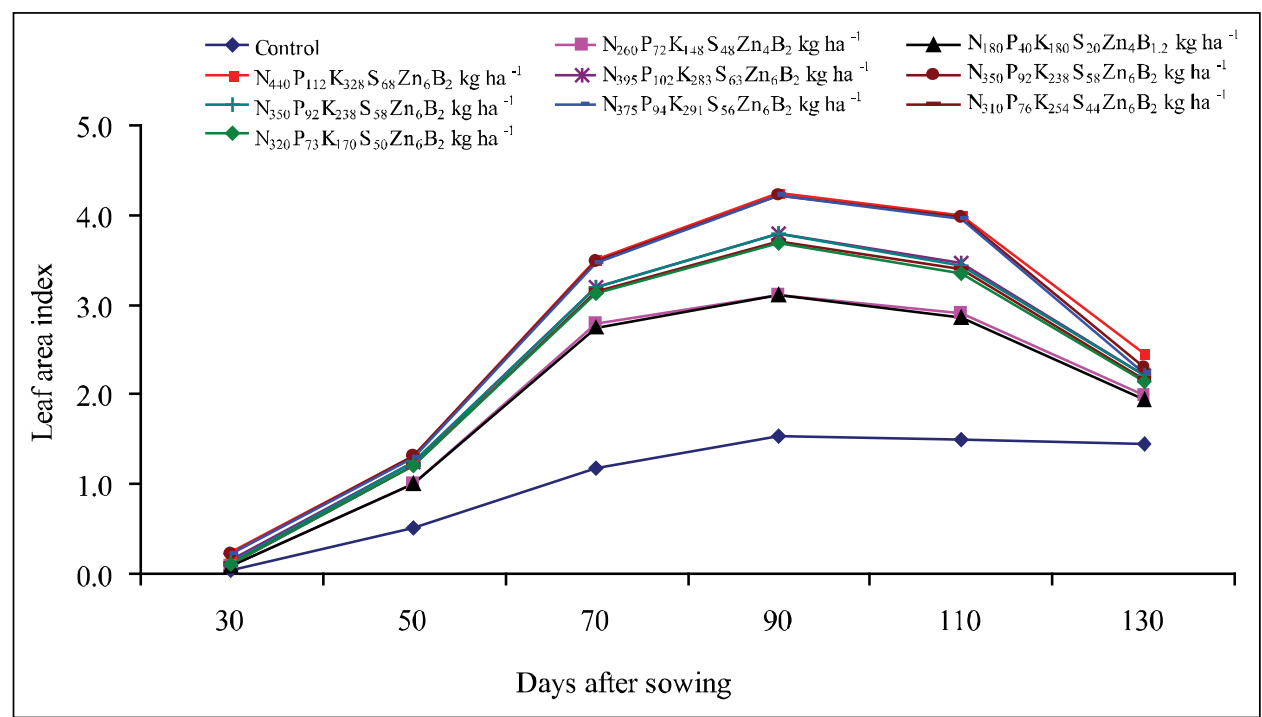

Fig. 4. Leaf area index of hybrid maize in potato hybrid maize intercropping system under different fertilizer level over days after sowing. 


\section{Total dry matter of potato and hybrid maize}

Total dry matter of intercropped potato and maize increased progressively over time and there was significantly difference in the pattern of biomass accumulation under different fertilizer levels (Figs. 5 and 6). In the beginning of the growth, the different in dry matter of both crops across different fertilizer levels was less conspicuous but it widened over time in both crops. Dry matter increased sharply up to 60 DAP and 110 DAS in potato and maize, respectively, and then slowly up to harvest. Higher rate of dry matter accumulation at this growth phase might be due to development of higher leaf area. The plants grown without added fertilizer produced the lowest dry matter and it increased with the increase of fertilizer levels. In general, higher the level of fertilizer, greater was the dry matter production of both the crops at all the growth stages. The increased level of added fertilizer might be due to increased photosynthetic rate resulting in higher leaf area and thereby increased dry matter production. It indicate that a greater amount of fertilizer was needed to sustain growth and development of the crop. Dry matter production is largely a function of photosynthetic area that might be due to higher level of fertilizer/ nutrients. Jha et al. (2000 and 2002) also observed the same phenomenon when maize was intercropped with potato. The TDM of potato and maize was found positively correlated with tuber yield $(r=0.99)$ and grain yield $(r=0.99)$, respectively.

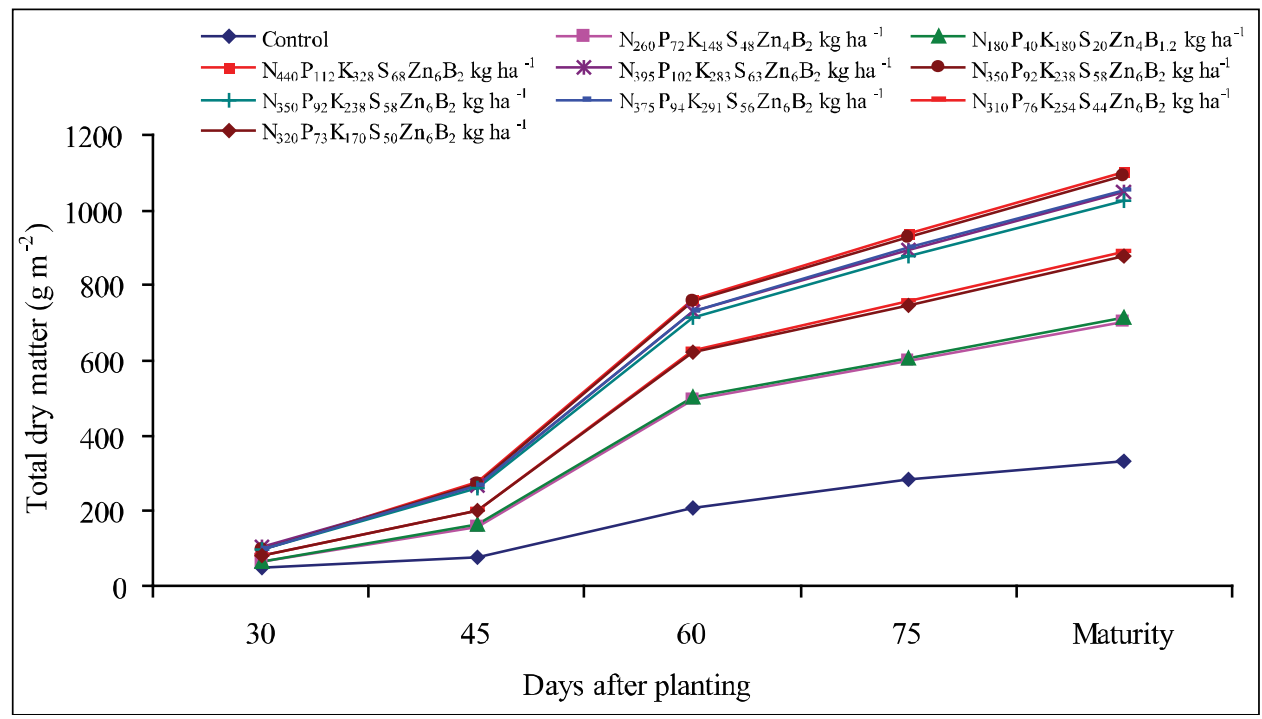

Fig. 5. Total dry matter of potato in potato hybrid maize intercropping system under different fertilizer level over days after planting. 


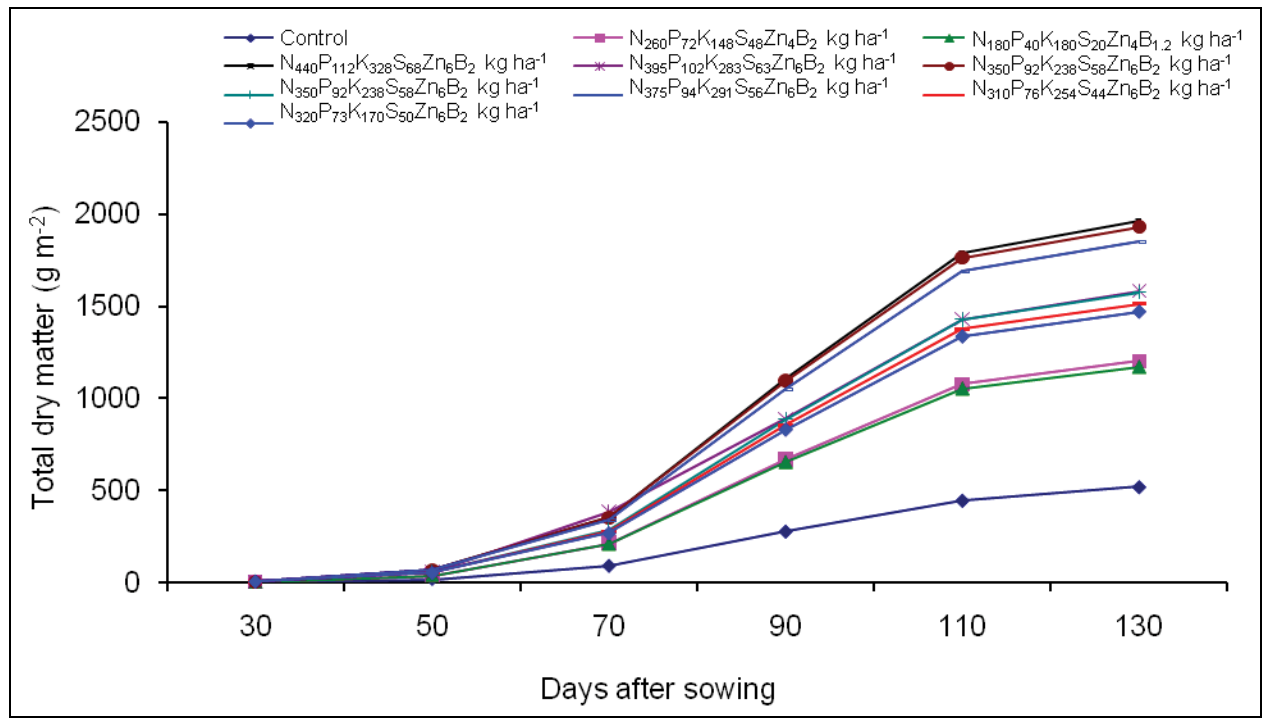

Fig. 6. Total dry matter of hybrid maize in potato hybrid maize intercropping system under different fertilizer level over days aster sowing.

\section{Effect on potato}

The fertilizer packages had significant impact on number of stems $\mathrm{m}^{-2}$, number of tubers hill ${ }^{-1}$, tuber weight hill-1 and tuber yield ha ${ }^{-1}$ (Table 1). The highest number of stems $\mathrm{m}^{-2}$ (37.33) was observed in $\mathrm{F}_{4}(100 \% \mathrm{RF}$ for $\mathrm{HM}+100 \% \mathrm{RF}$ for potato) and $\mathrm{F}_{6}(100 \% \mathrm{RF}$ for $\mathrm{HM}+75 \% \mathrm{RF}$ for potato) and these two treatments were significantly different from other treatments. These results are in agreement with the findings of Jahan (2011). Control treatment gave the lowest number of stems $\mathrm{m}^{-2}$ due to poor nutrient effect. The highest two fertilizer levels gave the highest number of stems $\mathrm{m}^{-2}$ due to producing vigorous vegetative growth. Constantin et al. (1974) reported that excess fertilizer dose produced unusual vegetative growth. The maximum number of tubers hill $^{-1}$ was recorded in $\mathrm{N}_{375} \mathrm{P}_{94} \mathrm{~K}{ }_{291} \mathrm{~S}_{56} \mathrm{Zn}_{6} \mathrm{~B}_{2} \mathrm{~kg}^{-1}$ which was at per with those in $\mathrm{F}_{4}, \mathrm{~F}_{5}, \mathrm{~F}_{6}, \mathrm{~F}_{7}, \mathrm{~F}_{8}, \mathrm{~F}_{9}$ and $\mathrm{F}_{10}$ treatments. Application of $\mathrm{N}_{440} \mathrm{P}_{112} \mathrm{~K}_{328} \mathrm{~S}_{68} \mathrm{Zn}_{6} \mathrm{~B}_{2} \mathrm{~kg}^{\mathrm{kg}}{ }^{-1}$ tended to decrease number of tubers hill ${ }^{-1}$ might be due to excess fertilizer produced unusual vegetative growth. Plants grown without added fertilizer produced the lowest tubers hill ${ }^{-1}$. Similar result was found by Akhteruzzaman et al. (2008). They reported that number of tubers hill ${ }^{-1}$ increased progressively with the increase of fertilizer up to $\mathrm{N}_{320} \mathrm{P}_{73} \mathrm{~K}_{170} \mathrm{~S}_{50} \mathrm{Zn}_{6} \mathrm{~B}_{2} \mathrm{~kg} \mathrm{ha}^{-1}$. The weight of tubers hill ${ }^{-1}$ was improved with corresponding increase of fertilizer levels up to $\mathrm{N}_{375} \mathrm{P}_{94} \mathrm{~K}_{291} \mathrm{~S}_{56} \mathrm{Zn}_{6} \mathrm{~B}_{2} \mathrm{~kg} \mathrm{ha}^{-1}$. But beyond $\mathrm{N}_{350} \mathrm{P}_{92} \mathrm{~K}_{283} \mathrm{~S}_{58} \mathrm{Zn}_{6} \mathrm{~B}_{2} \mathrm{~kg} \mathrm{ha}^{-1}$ the increase was minimal. More or less similar result was found by Akhteruzzaman et al. (2008). The results also revealed that beyond $\mathrm{N}_{375} \mathrm{P}_{94} \mathrm{~K}_{291} \mathrm{~S}_{56} \mathrm{Zn}_{6} \mathrm{~B}_{2} \mathrm{~kg} \mathrm{ha}^{-1}$, the weight of tubers hill ${ }^{-1}$ was decreased might be attributed to mutual shading 
resulting from vigorous vegetative growth. The results are in agreement with the findings of Reed et al. (1988). Tuber yield of potato differed significantly under different fertilizer management practices in potato hybrid maize intercropping system (Table 1). The highest tuber yield was obtained from $\mathrm{N}_{375} \mathrm{P}_{94} \mathrm{~K}_{291} \mathrm{~S}_{56} \mathrm{Zn}_{6} \mathrm{~B}_{2}$ $\mathrm{kg} \mathrm{ha} \mathrm{ha}^{-1}$ and it was statistically identical with $\mathrm{N}_{440} \mathrm{P}_{112} \mathrm{~K}_{328} \mathrm{~S}_{68} \mathrm{Zn}_{6} \mathrm{~B}_{2}$, $\mathrm{N}_{352} \mathrm{P}_{90} \mathrm{~K}_{262} \mathrm{~S}_{54} \mathrm{Zn}_{6} \mathrm{~B}_{2}, \quad \mathrm{~N}_{395} \mathrm{P}_{102} \mathrm{~K}_{283} \mathrm{~S}_{63} \mathrm{Zn}_{6} \mathrm{~B}_{2}, \quad \mathrm{~N}_{350} \mathrm{P}_{92} \mathrm{~K}_{283} \mathrm{~S}_{8} \mathrm{Zn}_{6} \mathrm{~B}_{2} \quad \mathrm{~kg} \mathrm{ha}^{-1}$. This might be due to the combined effect of higher number of tubers hill ${ }^{-1}$ and tuber weight hill $^{-1}$. It was also observed that number of tubers hill ${ }^{-1}$ had positive correlation with tuber yield $(\mathrm{r}=0.99)$. Application of fertilizer beyond $\mathrm{N}_{375} \mathrm{P}_{94} \mathrm{~K}_{291} \mathrm{~S}_{56} \mathrm{Zn}_{6} \mathrm{~B}_{2} \mathrm{~kg} \mathrm{ha}^{-1}$ of, tuber yield slightly decreased due to vigorous vegetative growth. Constantin et al. (1974) reported that excess fertilizer reduced crop yield through producing unusual vegetative growth. The lowest tuber yield was obtained where potato was grown without applying any fertilizer.

Table 1. Yield and yield components of potato in potato hybrid maize intercropping system under different fertilizer level

\begin{tabular}{lcc|c|c}
\hline $\begin{array}{c}\text { Fertilizer level } \\
\left(\mathrm{kg} \mathrm{ha}^{-1}\right)\end{array}$ & $\begin{array}{c}\text { Stems m}^{-2} \\
(\text { no. })\end{array}$ & $\begin{array}{c}\text { Tubers hill } \\
(\mathrm{no})\end{array}$ & $\begin{array}{c}\text { Tuber weight } \\
\text { hill }^{-1}(\mathrm{~g})\end{array}$ & $\begin{array}{c}\text { Tuber yield } \\
\left(\mathrm{t} \mathrm{ha}^{-1}\right)\end{array}$ \\
\hline $0-0-0-0-0-0\left(\mathrm{~F}_{1}\right)$ & $14.93 \mathrm{c}$ & $4.50 \mathrm{~d}$ & $150.23 \mathrm{e}$ & $9.02 \mathrm{e}$ \\
$\mathrm{N}_{260} \mathrm{P}_{72} \mathrm{~K}_{148} \mathrm{~S}_{48} \mathrm{Zn}_{4} \mathrm{~B}_{2}\left(\mathrm{~F}_{2}\right)$ & $29.33 \mathrm{~b}$ & $6.50 \mathrm{c}$ & $300.15 \mathrm{~d}$ & $18.01 \mathrm{~d}$ \\
$\mathrm{~N}_{180} \mathrm{P}_{40} \mathrm{~K}_{180} \mathrm{~S}_{20} \mathrm{Zn}_{4} \mathrm{~B}_{1.2}\left(\mathrm{~F}_{3}\right)$ & $29.87 \mathrm{~b}$ & $7.20 \mathrm{bc}$ & $364.80 \mathrm{~cd}$ & $19.39 \mathrm{~cd}$ \\
$\mathrm{~N}_{440} \mathrm{P}_{112} \mathrm{~K}_{328} \mathrm{~S}_{68} \mathrm{Zn}_{6} \mathrm{~B}_{2}\left(\mathrm{~F}_{4}\right)$ & $37.33 \mathrm{a}$ & $10.00 \mathrm{a}$ & $550.25 \mathrm{ab}$ & $29.00 \mathrm{ab}$ \\
$\mathrm{N}_{352} \mathrm{P}_{90} \mathrm{~K}_{262} \mathrm{~S}_{54} \mathrm{Zn}_{6} \mathrm{~B}_{2}\left(\mathrm{~F}_{5}\right)$ & $30.93 \mathrm{~b}$ & $10.20 \mathrm{a}$ & $580.90 \mathrm{a}$ & $30.00 \mathrm{a}$ \\
$\mathrm{N}_{395} \mathrm{P}_{102} \mathrm{~K}_{283} \mathrm{~S}_{63} \mathrm{Zn}_{6} \mathrm{~B}_{2}\left(\mathrm{~F}_{6}\right)$ & $37.33 \mathrm{a}$ & $10.20 \mathrm{a}$ & $575.20 \mathrm{a}$ & $29.50 \mathrm{ab}$ \\
$\mathrm{N}_{350} \mathrm{P}_{92} \mathrm{~K}_{238} \mathrm{~S}_{58} \mathrm{Zn}_{6} \mathrm{~B}_{2}\left(\mathrm{~F}_{7}\right)$ & $30.67 \mathrm{~b}$ & $10.20 \mathrm{a}$ & $579.12 \mathrm{a}$ & $29.80 \mathrm{ab}$ \\
$\mathrm{N}_{375} \mathrm{P}_{94} \mathrm{~K}_{291} \mathrm{~S}_{56} \mathrm{Zn}_{6} \mathrm{~B}_{2}\left(\mathrm{~F}_{8}\right)$ & $31.47 \mathrm{~b}$ & $10.45 \mathrm{a}$ & $600.25 \mathrm{a}$ & $30.20 \mathrm{a}$ \\
$\mathrm{N}_{310} \mathrm{P}_{76} \mathrm{~K}_{254} \mathrm{~S}_{44} \mathrm{Zn}_{6} \mathrm{~B}_{2}\left(\mathrm{~F}_{9}\right)$ & $30.40 \mathrm{~b}$ & $8.70 \mathrm{ab}$ & $460.15 \mathrm{bc}$ & $24.10 \mathrm{bc}$ \\
$\mathrm{N}_{320} \mathrm{P}_{73} \mathrm{~K}_{170} \mathrm{~S}_{50} \mathrm{Zn}_{6} \mathrm{~B}_{2}\left(\mathrm{~F}_{10}\right)$ & $30.13 \mathrm{~b}$ & $8.70 \mathrm{ab}$ & $455.10 \mathrm{bc}$ & $23.00 \mathrm{~cd}$ \\
\hline $\mathrm{CV}(\%)$ & 6.25 & 8.66 & 9.15 & 9.93 \\
\hline
\end{tabular}

In a column, figures having common or without letter (s) do not differ significantly whereas the figures with dissimilar letter differ significantly at $5 \%$ level of probability.

\section{Effect on maize}

Yield and yield attributes of hybrid maize were significantly affected by fertilizer dose except number of cobs $\mathrm{m}^{-2}$ (Table 2). The highest level of NPKSZnB gave longest and thickest cob which was statistically similar to those of all the treatments except control and $\mathrm{N}_{180} \mathrm{P}_{40} \mathrm{~K}_{180} \mathrm{~S}_{20} \mathrm{Zn}_{4} \mathrm{~B}_{2} \mathrm{~kg} \mathrm{ha}^{-1}$. It might be due to poor nutrient in control and $100 \% \mathrm{RF}$ for potato. The results are in agreement with Islam (2007). He reported that when potato was intercropped with maize under different level of NPK, cob length and diameter was similar except $100 \%$ $\mathrm{RF}$ for hybrid maize $+0 \% \mathrm{RF}$ for potato and $100 \% \mathrm{RF}$ for $\mathrm{HM}+25 \% \mathrm{RF}$ for 
potato of NPK levels. Number of grains $\mathrm{cob}^{-1}$ and weight of 1000-grain of maize was found to be the lowest with the lowest level of NPKSZnB and then it was increased with the corresponding increase of NPKSZnB level up to the highest, though beyond $\mathrm{N}_{320} \mathrm{P}_{73} \mathrm{~K}_{170} \mathrm{~S}_{50} \mathrm{Zn}_{6} \mathrm{~B}_{2} \mathrm{~kg} \mathrm{ha}^{-1}$ the increase was marginal. This, perhaps, might be due to more availability of nutrients as well as better absorption and conversion of the resources to the grain. Jha et al. (2000 and 2002) also reported that the number of grains $\mathrm{cob}^{-1}$ and weight of 1000-grain of maize increased with the increase of NPK level up to 75\%. Islam (2007) also reported that 1000-grain weight of intercropped maize with potato increased with the increase of NPK levels up to the highest (100\% of RF for potato used with $100 \% \mathrm{RF}$ for $\mathrm{HM}$ ) in maize + potato intercropping system. Grain yield of maize differed significantly in potato hybrid maize intercropping system under different fertilizer management practices (Table 2). The lower fertilizer level gave lower grain yield of maize. Subsequently, it was increased with each successive increment up to $\mathrm{N}_{440} \mathrm{P}_{112} \mathrm{~K}_{328} \mathrm{~S}_{68} \mathrm{Zn}_{6} \mathrm{~B}_{2} \mathrm{~kg} \mathrm{ha}^{-1}$ and it was statistically identical with $\mathrm{N}_{395}-\mathrm{P}_{102} \mathrm{~K}_{283} \mathrm{~S}_{63} \mathrm{Zn}_{6} \mathrm{~B}_{2} \mathrm{~kg} \mathrm{ha}^{-1}$ (100\% RF for $\mathrm{HM}+75 \% \mathrm{RF}$ for potato) and $\mathrm{N}_{375} \mathrm{P}_{94} \mathrm{~K}_{191} \mathrm{~S}_{56} \mathrm{Zn}_{6} \mathrm{~B}_{2} \mathrm{~kg} \mathrm{ha}^{-1}$ (100\% RF for potato $+75 \% \mathrm{RF}$ for $\mathrm{HM}$ ). The higher yield of hybrid maize in aforesaid treatment was attributed to the cumulative effect of grains $\mathrm{cob}^{-1}$ and 1000-grain weight. A close relationship between grain yield and number of grains $\mathrm{cob}^{-1}(\mathrm{r}=0.99)$ and 1000 -grain weight $(\mathrm{r}=0.95)$ was observed. Kumar et al. (2000) observed that the full RF for maize $+75 \%$ RF for potato gave the highest yield. The results are in agreement with the findings of Jha et al. (2000) and Islam (2007) in maize + potato intercropping. The lowest grain yield of maize was found from control treatment (without added fertilizer).

Table 2. Yield and yield components of hybrid maize in potato hybrid maize intercropping under different fertilizer level

\begin{tabular}{|c|c|c|c|c|c|c|}
\hline $\begin{array}{l}\text { Fertilizer level } \\
\qquad\left(\mathrm{kg} \mathrm{ha}^{-1}\right)\end{array}$ & $\begin{array}{c}\text { Cobs } \\
\mathrm{m}^{-2} \\
\text { (no.) }\end{array}$ & $\begin{array}{l}\text { Cob } \\
\text { length } \\
(\mathrm{cm})\end{array}$ & $\begin{array}{c}\text { Cob } \\
\text { diameter } \\
(\mathrm{cm})\end{array}$ & $\begin{array}{c}\text { Grains } \\
\text { cob }^{-1} \\
\text { (no.) }\end{array}$ & $\begin{array}{c}\text { 1000-grain } \\
\text { weight } \\
(\mathrm{g})\end{array}$ & $\begin{array}{c}\text { Grain } \\
\text { yield } \\
\left(\mathrm{t} \mathrm{ha}^{-1}\right)\end{array}$ \\
\hline $0-0-0-0-0-0\left(\mathrm{~F}_{1}\right)$ & 6.10 & $13.00 \mathrm{c}$ & $3.20 \mathrm{c}$ & $204.20 f$ & $200.50 \mathrm{~d}$ & $2.49 \mathrm{~d}$ \\
\hline $\mathrm{N}_{260} \mathrm{P}_{72} \mathrm{~K}_{148} \mathrm{~S}_{48} \mathrm{Zn}_{4} \mathrm{~B}_{2}\left(\mathrm{~F}_{2}\right)$ & 6.57 & $19.50 \mathrm{ab}$ & 4.60ab & $448.50 \mathrm{e}$ & $306.50 \mathrm{bc}$ & $6.05 c$ \\
\hline $\mathrm{N}_{180} \mathrm{P}_{40} \mathrm{~K}_{180} \mathrm{~S}_{20} \mathrm{Zn}_{4} \mathrm{~B}_{1.2}\left(\mathrm{~F}_{3}\right)$ & 6.29 & $15.00 \mathrm{bc}$ & $4.30 \mathrm{~b}$ & $442.70 \mathrm{e}$ & $300.50 \mathrm{c}$ & $5.90 \mathrm{c}$ \\
\hline $\mathrm{N}_{440} \mathrm{P}_{112} \mathrm{~K}_{328} \mathrm{~S}_{68} \mathrm{Zn}_{6} \mathrm{~B}_{2}\left(\mathrm{~F}_{4}\right)$ & 6.67 & $22.10 \mathrm{a}$ & $5.30 \mathrm{a}$ & $650.20 \mathrm{a}$ & $345.50 \mathrm{a}$ & $10.00 \mathrm{a}$ \\
\hline $\mathrm{N}_{352} \mathrm{P}_{90} \mathrm{~K}_{262} \mathrm{~S}_{54} \mathrm{Zn}_{6} \mathrm{~B}_{2}\left(\mathrm{~F}_{5}\right)$ & 6.66 & $21.00 \mathrm{a}$ & $5.20 \mathrm{a}$ & $570.30 b$ & $325.70 \mathrm{abc}$ & $8.03 b$ \\
\hline $\mathrm{N}_{395} \mathrm{P}_{102} \mathrm{~K}_{283} \mathrm{~S}_{63} \mathrm{Zn}_{6} \mathrm{~B}_{2}\left(\mathrm{~F}_{6}\right)$ & 6.67 & $21.00 \mathrm{a}$ & $5.30 \mathrm{a}$ & $630.50 \mathrm{a}$ & $341.00 \mathrm{ab}$ & $9.91 \mathrm{a}$ \\
\hline $\mathrm{N}_{350} \mathrm{P}_{92} \mathrm{~K}_{238} \mathrm{~S}_{58} \mathrm{Zn}_{6} \mathrm{~B}_{2}\left(\mathrm{~F}_{7}\right)$ & 6.65 & $20.00 \mathrm{a}$ & 4.90ab & $560.20 \mathrm{bc}$ & $323.20 \mathrm{abc}$ & $8.00 \mathrm{~b}$ \\
\hline $\mathrm{N}_{375} \mathrm{P}_{94} \mathrm{~K}_{291} \mathrm{~S}_{56} \mathrm{Zn}_{6} \mathrm{~B}_{2}\left(\mathrm{~F}_{8}\right)$ & 6.67 & $21.00 \mathrm{a}$ & $4.87 \mathrm{ab}$ & $624.50 \mathrm{a}$ & $339.50 \mathrm{ab}$ & $9.48 \mathrm{a}$ \\
\hline $\mathrm{N}_{310} \mathrm{P}_{76} \mathrm{~K}_{254} \mathrm{~S}_{44} \mathrm{Zn}_{6} \mathrm{~B}_{2}\left(\mathrm{~F}_{9}\right)$ & 6.64 & $20.00 \mathrm{a}$ & 4.70ab & $530.20 \mathrm{~cd}$ & $318.50 \mathrm{abc}$ & $7.72 b$ \\
\hline $\mathrm{N}_{320} \mathrm{P}_{73} \mathrm{~K}_{170} \mathrm{~S}_{50} \mathrm{Zn}_{6} \mathrm{~B}_{2}\left(\mathrm{~F}_{10}\right)$ & 6.62 & $20.00 \mathrm{a}$ & $4.65 \mathrm{ab}$ & $500.50 \mathrm{~d}$ & $316.20 \mathrm{abc}$ & $7.50 \mathrm{~b}$ \\
\hline $\mathrm{CV}(\%)$ & 3.93 & 10.15 & 7.49 & 3.03 & 4.73 & 6.30 \\
\hline
\end{tabular}

In a column figures having common or without letter (s) do not differ significantly whereas the figures with dissimilar letter differ significantly at $5 \%$ level of probability. 


\section{Evaluation of intercrop productivity and economic performance}

The performance of potato hybrid maize intercropping was evaluated on the basis of equivalent yield (Bandyopadhyay, 1984) and monetary advantage (Shah et al., 1991) are presented in Table 3. There was a trend of increase in potato equivalent yield (PEY) with the increase of fertilizer level up to $\mathrm{N}_{375} \mathrm{P}_{94} \mathrm{~K}_{291} \mathrm{~S}_{56} \mathrm{Zn}_{6} \mathrm{~B}_{2} \mathrm{~kg} \mathrm{ha}^{-1}$ (100\% RF for potato $+75 \%$ RF for HM) and then declined (Table 3). The PEY was decreased considerably towards lower fertilizer levels. The highest PEY was recorded in $100 \% \mathrm{RF}$ for potato $+75 \% \mathrm{RF}$ for $\mathrm{HM}$ which covering the yield advantage of $245 \%$ over control. The higher PEY was mainly attributed due to additional yield advantage resulted from fertilizer effect in potato hybrid maize intercropping. Akhteruzzaman et al. (2008) also reported PEY increased towards higher fertilizer rates of $\mathrm{N}_{320} \mathrm{P}_{73} \mathrm{~K}_{170} \mathrm{~S}_{50} \mathrm{Zn}_{6} \mathrm{~B}_{2} \mathrm{~kg}^{-1}$ in potato hybrid maize intercropping. The lowest PEY $\left(11.72 \mathrm{t} \mathrm{ha}^{-1}\right)$ was observed in $\mathrm{F}_{1}$ (control) treatment. The highest gross return (Tk. $526110 \mathrm{ha}^{-1}$ ) was achieved from $\mathrm{N}_{375} \mathrm{P}_{94} \mathrm{~K}_{291} \mathrm{~S}_{56} \mathrm{Zn}_{6} \mathrm{~B}_{2} \mathrm{~kg}^{-1}$ and it decreased at the highest two fertilizer levels $\left(\mathrm{N}_{440} \mathrm{P}_{112} \mathrm{~K}_{328} \mathrm{~S}_{68} \mathrm{Zn}_{6} \mathrm{~B}_{2}\right.$ and $\left.\mathrm{N}_{395} \mathrm{P}_{102} \mathrm{~K}_{283} \mathrm{~S}_{63} \mathrm{Zn}_{6} \mathrm{~B}_{2} \mathrm{~kg} \mathrm{ha}^{-1}\right)$. Cost of production increased with increasing fertilizer level. However, the highest cost of production was observed in $\mathrm{F}_{4}$ (Tk. 150347 ha $^{-1}$ ). Gross margin and benefit cost ratio (BCR) increased with corresponding increase up to $\mathrm{N}_{375} \mathrm{P}_{94} \mathrm{~K}_{291} \mathrm{~S}_{56} \mathrm{Zn}_{6} \mathrm{~B}_{2} \mathrm{~kg} \mathrm{ha}^{-1}$ then it was declined with further increase of NPKSZnB. The highest gross margin (Tk.381957 ha ${ }^{-1}$ ) and BCR (3.65) were observed when potato hybrid maize intercropping system was fertilized with $\mathrm{N}_{375} \mathrm{P}_{94} \mathrm{~K}_{291} \mathrm{~S}_{56} \mathrm{Zn}_{6} \mathrm{~B}_{2} \mathrm{~kg}$ ha ${ }^{-1}$ (100\% RF for potato $+75 \%$ RF for HM). So, fertilizer rate of $\mathrm{N}_{375} \mathrm{P}_{94} \mathrm{~K}_{291} \mathrm{~S}_{56} \mathrm{Zn}_{6} \mathrm{~B}_{2} \mathrm{~kg}^{-1}$ would be the most potential fertilizer dose for potato hybrid maize intercropping system. Islam (2007) reported more or less similar results in hybrid maize + potato intercropping.

Table 3. Potato equivalent yield (PEY) and benefit cost analysis of potato hybrid maize intercropping system as influenced by different fertilizer level

\begin{tabular}{|c|c|c|c|c|c|}
\hline $\begin{array}{l}\text { Fertilizer level } \\
\quad\left(\mathrm{kg} \mathrm{ha}^{-1}\right)\end{array}$ & $\begin{array}{l}\text { PEY } \\
\left(\mathrm{t} \mathrm{ha}^{-1}\right)\end{array}$ & $\begin{array}{c}\text { Gross } \\
\text { return } \\
\left(\text { Tk. ha }^{-1}\right)\end{array}$ & $\begin{array}{l}\text { Cost of } \\
\text { production } \\
\left(\text { Tk. ha }^{-1}\right)\end{array}$ & $\begin{array}{c}\text { Gross margin } \\
\left(\mathrm{Tk} \cdot \mathrm{ha}^{-1}\right)\end{array}$ & $\begin{array}{l}\text { Benefit cost } \\
\text { ratio (BCR) }\end{array}$ \\
\hline $0-0-0-0-0-0\left(F_{1}\right)$ & 11.72 & 152360 & 102516 & 49844 & 1.49 \\
\hline $\mathrm{N}_{260} \mathrm{P}_{72} \mathrm{~K}_{148} \mathrm{~S}_{48} \mathrm{Zn}_{4} \mathrm{~B}_{2}\left(\mathrm{~F}_{2}\right)$ & 24.56 & 319280 & 130800 & 188480 & 2.44 \\
\hline $\mathrm{N}_{180} \mathrm{P}_{40} \mathrm{~K}_{180} \mathrm{~S}_{20} \mathrm{Zn}_{4} \mathrm{~B}_{1.2}\left(\mathrm{~F}_{3}\right)$ & 25.78 & 335140 & 124098 & 211042 & 2.70 \\
\hline $\mathrm{N}_{440} \mathrm{P}_{112} \mathrm{~K}_{328} \mathrm{~S}_{68} \mathrm{Zn}_{6} \mathrm{~B}_{2}\left(\mathrm{~F}_{4}\right)$ & 39.83 & 517790 & 150347 & 367443 & 3.44 \\
\hline $\mathrm{N}_{352} \mathrm{P}_{90} \mathrm{~K}_{262} \mathrm{~S}_{54} \mathrm{Zn}_{6} \mathrm{~B}_{2}\left(\mathrm{~F}_{5}\right)$ & 38.70 & 503100 & 141582 & 361518 & 3.55 \\
\hline $\mathrm{N}_{395} \mathrm{P}_{102} \mathrm{~K}_{283} \mathrm{~S}_{63} \mathrm{Zn}_{6} \mathrm{~B}_{2}\left(\mathrm{~F}_{6}\right)$ & 40.24 & 523120 & 145581 & 377539 & 3.59 \\
\hline $\mathrm{N}_{350} \mathrm{P}_{92} \mathrm{~K}_{238} \mathrm{~S}_{58} \mathrm{Zn}_{6} \mathrm{~B}_{2}\left(\mathrm{~F}_{7}\right)$ & 38.47 & 500110 & 140821 & 359289 & 3.55 \\
\hline $\mathrm{N}_{375} \mathrm{P}_{94} \mathrm{~K}_{291} \mathrm{~S}_{56} \mathrm{Zn}_{6} \mathrm{~B}_{2}\left(\mathrm{~F}_{8}\right)$ & 40.47 & 526110 & 144153 & 381957 & 3.65 \\
\hline $\mathrm{N}_{310} \mathrm{P}_{76} \mathrm{~K}_{254} \mathrm{~S}_{44} \mathrm{Zn}_{6} \mathrm{~B}_{2}\left(\mathrm{~F}_{9}\right)$ & 32.46 & 421980 & 137971 & 284009 & 3.06 \\
\hline $\mathrm{N}_{320} \mathrm{P}_{73} \mathrm{~K}_{170} \mathrm{~S}_{50} \mathrm{Zn}_{6} \mathrm{~B}_{2}\left(\mathrm{~F}_{10}\right)$ & 31.13 & 404690 & 134077 & 270613 & 3.02 \\
\hline
\end{tabular}

Market price: Potato -Tk. $13 \mathrm{~kg}^{-1}$; Maize- Tk. $14 \mathrm{~kg}^{-1}$. 


\section{Conclusion}

The results revealed that fertilizer at the rate of $\mathrm{N}_{375} \mathrm{P}_{94} \mathrm{~K}_{291} \mathrm{~S}_{56} \mathrm{Zn}_{6} \mathrm{~B}_{2} \mathrm{~kg} \mathrm{ha}^{-1}$ (100\% recommended fertilizer for potato $+75 \%$ recommended fertilizer for hybrid maize) might be optimum for potato hybrid maize intercropping system for achieving higher productivity and economic return.

\section{References}

Akhtar, M.E., M.S. Ali, Z.N. Huq, A.K.M.A.Habib, M.A.Hoque and A.B.S. Hossain 1998. Problems and Prospects of Tuber Crops in Bangladesh. In: Workshop on Transfer of Technology of CDP Crops and Research Extension Linkage Programme. Oct. 22-27, 1994. Bangladesh Agril. Res. Inst., Joydebpur, Gazipur, Bangladesh. Pp. 213-220.

Akhteruzzaman, M., M.N. Islam, B.L. Nag and M.T. Rahman. 2008. Productivity of potato-hybrid maize intercropping under different fertilizer levels. Eco-friendly Agril. J. 1(5) 300-303.

Bandyopadhyay, S.N. 1984. Nitrogen and water relations in grain sorghum legume intercropping systems, Ph.D. Thesis, Indian Agril. Res. Inst., New Delhi.

Biscoe, P.V. and J.N. Gallagher. 1977. Weather, dry matter production and yield. In: J.J. Landsberg and C.V. Cutting (eds.), Environmental Effects on Crop Physiology. Academic Press, London. Pp. 75-100.

Chand, S. P., H. C. Lee, D. H. Scarisbrick, F. E. Tollervey. 2001. Potato (Solanum tuberosum L.) intercropped with maize (Zea mays L.) in the Eastern Hills of Nepal. Japanese J. Trop. Agric. 45(3):167-175.

Constantin, R.J., T.P. Hernandez and L.G. Jones. 1974. Effect of irrigation and nitrogen on the quality of sweet potato. J. Amer. Soc. Hort. Sci. 99 308-310.

Flenet, F., J. Kiniry, J. Board, M. Westgate and D.C. Reicosky. 1996. Row spacing effects on light extinction coefficients of corn, sorghum, soybean and sunflower. Agron. J. 88 185-190.

Hossain, M., T.K. Dey, S. Akhter, M. K. R. Bhuiyan, M. A. Hoque, B.C. Kunda, M. A. Hossain and S.N. Begum. 2008. Activities and achievements of Tuber Crops Research Centre at a glance. Bulletin published by the Tuber Crops Research Centre, BARI, Gazipur. 23p.

Islam, M.Z. 2007. Production potential of maize oriented intercropping as influenced by NPK level and row arrangement, Ph.D. Thesis, Dept. Agron., Bangladesh Agril. Univ., Mymensingh, Bangladesh. Pp.64-163.

Jahan, M.A.H.S. 2011. The effect of nutrient management on the productivity of PotatoMungbean-T. aman rice cropping pattern, Ph.D. Thesis, Dept. Agron., Bangladesh Agril. Univ., Mymensingh, Bangladesh. Pp.47-82.

Jha, G., D.P. Singh, S.K. Varshney, S. Jumar, S.M.P. Khurana, G.S. Shekhawat, S.K. Pandey and B.P. Singh (ed.). 2002. Fertilizer requirement of winter maize +potato 
intercropping system. In: Proc. of the Global conf. Potato, New Delhi, India, 6-11 December 1999. 2: 974-977.

Jha, G., D.P. Singh and R.B. Thakur. 2000. Production potential of maize + potato intercropping as influenced by fertilizer and potato genotypes. Indian J. Agron. 45(1): 59-63.

Kumar, C.A., S. Kumar and G.P. Srivastava. 2000. Production potential and fertilizer economy in winter maize + potato based intercropping system. Orissa J. Hort. 28 (1): 51-55.

Maddonni G.A. and M.E. Otegui. 2004. Intra-specific competition in maize: Early establishment of hierarchies among plant affects final kernel set. Field Crops Res. 85: $1-13$.

Morris, M. L., J. Risopoulos and D. Beek.1999. Genetic change in farmer-recycled maize (Zea mays L.) seed: a review of the evidence. CIMMYT- Economic workshop paper No. 90-97. Mexico D. F. CIMMYT. 1p.

Reed, J.A., G.W. Singletary, J.R. Schussler, D.R. Williamson and A.L. Christy. 1988. Shading effects on dry matter nitrogen partitioning kernel number and yield of maize. Crop Sci. 28: 819-825.

Santalla, M., P.A. Casquero, A.M. de Ron, 1999. Yield and yield components from intercropping improved bush bean cultivars with maize. Agron. Crop Sci. 183: 263269.

Santalla, M., A.P. Rodino, P.A. Casquero and A.M. de Ron. 2001. Interactions of bush bean intercropped with field and sweet maize. European J. Agron. 15: 185-196.

Shah, N.H., P.K. Koul, B.A. Khanday and D. Kachrov. 1991. Production potential and monetary advantage index of maize intercropped with different grain legumes. Indian J. Agron. 36(1): 23-28. 